baf- $\odot$

Proceedings of the Berner

Altorientalisches

Forum

ISSN 2504-2076

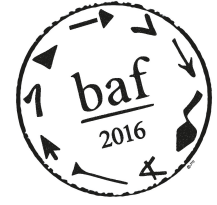

Abstract

Boaz Stavi, Oranim Academic College

DOI: http://dx.doi.org/10.22012/baf.2016.15

\title{
The Treatment of Troublesome Regions
}

It is quite clear that after the Old Hittite Kingdom had been established, the Hittites focused their attention on gaining control of Syria. At the same time, they also tried to expand to western Anatolia but soon learned that too great an involvement in the west left them vulnerable to attacks. From that time on, the kings of Hatti sought to keep their military involvement in western Anatolia to a minimum, while thwarting the emergence of any hostile coalitions there.

I find this subject fascinating - namely, how an empire that was founded on an ideology of expansion came to realize its natural boundaries and adjusted its ideology and practical strategy to extricate itself from a problematic region that could not be annexed or conquered. This specific case has been discussed only in part by Bryce (1986), so I decided to research it again in my dissertation. 